Research Article

\title{
Improved Corn Yields When Humic Acid Extracted from Composted Manure Is Applied to Acid Soils with Phosphorus Fertilizer
}

\author{
Benito H. Purwanto $\mathbb{D}^{1},{ }^{1}$ Putri Wulandari, ${ }^{2}$ Endang Sulistyaningsih $\mathbb{D}^{2},{ }^{2}$ Sri N. H. Utami $\mathbb{D}^{1}$ \\ and Suci Handayani $\mathbb{D}^{1}$ \\ ${ }^{1}$ Department of Soil Science, Faculty of Agriculture, Universitas Gadjah Mada, Bulaksumur, Yogyakarta 55281, Indonesia \\ ${ }^{2}$ Department of Agronomy, Faculty of Agriculture, Universitas Gadjah Mada, Bulaksumur, Yogyakarta 55281, Indonesia
}

Correspondence should be addressed to Benito H. Purwanto; benito@ugm.ac.id

Received 3 July 2020; Revised 13 December 2020; Accepted 30 December 2020; Published 12 January 2021

Academic Editor: Fedor Lisetskii

Copyright (c) 2021 Benito H. Purwanto et al. This is an open access article distributed under the Creative Commons Attribution License, which permits unrestricted use, distribution, and reproduction in any medium, provided the original work is properly cited.

\begin{abstract}
Most corn planted on tropical acidic soils suffers substantial yield loss caused by low crop phosphorus (P) uptake. Humic acid is recommended to increase crop $\mathrm{P}$ uptake since it is capable of competing with $\mathrm{P}$ to be bound to soil adsorption complexes. Humic acid extracted from composted manure (MHA) is a good alternative to humic acid because it is more reactive and has a higher complexation ability compared with leonardite. Therefore, the effectiveness of soil-applied MHA combined with P was evaluated to improve corn yields in acidic soils from the aspect of crop nutrient uptake efficiency and crop physiological performance. Two high-yielding corn cultivars that are highly accepted by Indonesian farmers and resistant to downy mildew disease were subjected to five different types of MHA and $\mathrm{P}$ combinations. The amount of $\mathrm{P}$ fertilizer was equivalent to $120 \mathrm{mg} \mathrm{P}_{2} \mathrm{O}_{5} \mathrm{~kg}^{-1}$ soil. The $\mathrm{H}_{10} \mathrm{P}_{1}$ produced the most significant result $(p<0.05)$ in terms of total crop dry weight, grain dry weight, and corn yield. The highest efficiency for $\mathrm{P}$ uptake in the leaves and grains was found with $\mathrm{H}_{10} \mathrm{P}_{1}$ and $\mathrm{H}_{5} \mathrm{P}_{1}$, respectively. Although chlorophyll content was not substantially improved, the stomatal apertures 7 weeks after planting (WAP) were significantly increased $(p<0.05)$ with $\mathrm{H}_{10} \mathrm{P}_{1}$ and $\mathrm{H}_{15} \mathrm{P}_{1}$. The photosynthetic rate and nitrate reductase (NR) activity at 10 WAP were significantly increased $(p<0.05)$ with $\mathrm{H}_{5} \mathrm{P}_{1}$ and $\mathrm{H}_{10} \mathrm{P}_{1}$, respectively. The results clearly indicated significant increases in the efficiency of crop $\mathrm{P}$ uptake and physiological performance for stomatal aperture, photosynthetic rate, and NR activity can highly contribute to higher corn yields.
\end{abstract}

\section{Introduction}

Corn, rice, and wheat are carbohydrate-producing food crops that are crucial for meeting the food demands of the increasing global population. Global yields from 1961 to 2008 for corn, rice, and wheat are increasing at $1.6 \%, 1.0 \%$, and $0.9 \%$ per year, respectively. However, those values are lower than the $2.4 \%$ per year rate required to double global production by 2050 , which implies that if the yield rates do not increase, then land clearing may be needed to maintain or increase global food production [1]. The FAO estimated that only $11 \%$ ( 1.5 billion ha) of the global land surface (13.4 billion ha) is currently used for crop production, and about
24\% (3.9 billion ha) is potentially arable, most of which (64\%; 2.5 billion ha) comprises acidic soils, with $68 \%(1.7$ billion ha) of acid soils located in the humid tropics [2]. Thus, these tropical acid soils represent potential areas for agricultural expansion. Corn planted on tropical acidic soils faces soil fertility problems during its growth, which hampers crop production, causing yield losses of up to $69 \%$ owing to its soil fertility constraints, including $\mathrm{pH}<5.5$, containing exchangeable aluminum ( $\mathrm{Al}$ ), and being deficient in essential nutrients, especially phosphorus (P) [3]. Acidic soils must be managed properly through soil amendments to increase agricultural production and improve sustainability. 
Commercial humic acid, which is mainly derived from lignitic coal, is widely used to improve soil and crop growth. Soil-applied humic acid derived from leonardite and lignitic coal has generally succeeded in increasing the crop yields of potatoes [4], wheat [5], lettuce [6], and corn [7]. However, the rate of humic acid applied to these soils varied greatly, which may be due to the different types of crops, different humification qualities of the humic acids, the content of soil exchangeable cations, and the soil texture. For example, to increase soybean yields, soils that have a high clay content require twice the amount of humic acid in comparison with coarse-textured soils [8]. However, from the perspective of sustainability, the use of lignitic coal-derived humic acid is inappropriate as it is a nonrenewable material [9]. Manure, composts, sludges, and lignin-rich crop residues are promising alternative sources of humic materials as well as being renewable [10]. Humic acid can be resynthesized from essential manure components, namely, amino acids, and from reduced sugar during the composting process [11]. Humic acid extracted from composted manure (MHA) has an aromatic compound composition with a low decomposition rate in soil [12]. It is also rich in carbonyl and phenolic compounds and is thus more reactive and has a higher complexation ability compared with leonardite [13]. This indicates that MHA may be a good alternative source of humic acid.

The effects of humic acid on the physiological aspects of corn have previously been investigated and substantial results were obtained. However, these previous studies were limited to solution cultures, growth-chamber-based studies, corn root seedlings treatments, and foliar applications of humic acid [14-18]. With nutrient solutions or foliar applications, humic acid will be in direct contact with the crop root or leaf tissues. However, when humic acid is applied to the soil, it can only be in direct contact with crop roots, substantially influencing the crops, but it may also first interact with soil components. In acidic soils with low available $\mathrm{P}$, humic acid will interact or compete with $\mathrm{P}$ to be bound to soil adsorption complexes, so that $\mathrm{P}$ becomes available in the soil and ready to be absorbed by the crops, but the interaction can also be negative with the formation of low solubility humic acid-metal-P [8]. However, the effectiveness of the addition of soil-applied humic acid combined with $\mathrm{P}$ from the aspect of crop nutrient uptake efficiency and crop physiology to improve corn yields, especially in soils with acidity problems and low available $\mathrm{P}$, has not been widely investigated. Therefore, the purpose of the present study was to evaluate (1) the effects of different MHA and P treatments on the availability of $\mathrm{P}$ in the soil, crop root attributes, and the efficiency of $\mathrm{P}$ uptake using two corn cultivars; and (2) the physiological responses of the crops to different combinations of the MHA and P, and their effects on improving the growth and yields of the two corn cultivars.

\section{Materials and Methods}

2.1. Soil Characterization. The soils were collected from the topsoil $(0-15 \mathrm{~cm})$ at Sukosari, Karanganyar District
(-7.639071 latitude, 110.949947 longitude), Tanggeran, Banyumas District (-7.316552 latitude, 109.236271 longitude), and Karangsalam, Banyumas District (-7.545819 latitude, 109.313377 longitude), Indonesia. The sampled soil was then air-dried, homogenized, and filtered using a $2 \mathrm{~mm}$ filter (soil properties are listed in Table 1). Sand, silt, and clay were determined via mechanical analysis using the pipette method based on Stokes' law following previously described procedures [19]. Soil $\mathrm{pH}$ was determined at a ratio of $1: 5$ (soil/distilled water suspension) using a $\mathrm{pH}$ meter, soil cation exchange capacity (CEC) and exchangeable cations were extracted by the $1 \mathrm{M}$ ammonium acetate method $(\mathrm{pH}$ 7.0), and the exchangeable cations were determined using a flame photometer (JENWAY PFPT7) for potassium (K) and sodium ( $\mathrm{Na}$ ) and using atomic absorption flame emission spectrophotometer (SHIMADZU AA-6200) for calcium (Ca) and magnesium (Mg). Available $\mathrm{P}$ was extracted using the Bray 1 method, followed by the molybdenum blue method, exchangeable $\mathrm{Al}$ was extracted by $1 \mathrm{~N}$ potassium chloride $(\mathrm{KCl})$, and the $\mathrm{Al}$ concentration in the $\mathrm{KCl}$ extract was determined using a UV-VIS spectrophotometer (SHIMADZU UV Mini 1240) following previously described procedures [20]. The soil $\mathrm{pH}$, soil available $\mathrm{P}$, and soil exchangeable $\mathrm{Al}$ were also measured at 15 weeks after planting (WAP).

2.2. Humic Acid and Phosphorus Fertilizer Source. The humic acid used in the present study was extracted from composted cow manure (MHA) produced by a corn farmer. The MHA used in this research contained 54\% $\mathrm{C}$ and $3.1 \% \mathrm{~N}$ and was shown to have numerous hydroxyl and carboxylic groups with strong absorption at 3425, 2924, 2855, and $1651 \mathrm{~cm}^{-1}$, as analyzed using a Fourier transform infrared spectrophotometer [21]. The extractant used was $0.1 \mathrm{M}$ sodium hydroxide $(\mathrm{NaOH})$ at a $1: 10(\mathrm{w} / \mathrm{v})$ compost extraction ratio. The humic acid extraction was conducted using previously described procedures [22]. The extracted humic acid was oven-dried at $40^{\circ} \mathrm{C}$ until it was a dry powder. $\mathrm{P}$ was sourced from commercial NPK compound fertilizer $(16: 16: 16)$ and ground prior to mixing with MHA. The MHA was then mixed homogenously with $\mathrm{P}$ fertilizer before being applied to the soils as combined MHA $+\mathrm{P}$ fertilizer.

2.3. Treatments and Design. This pot study was conducted in the research farm of the Faculty of Agriculture, Universitas Gadjah Mada, Yogyakarta, Indonesia. We used a factorial randomized complete block design with two factors and three soil sampling locations as blocks. Each block was replicated five times. The first factor $(\mathrm{C})$ was the two hybrid corn cultivars, Bisi 2 (CB) and Pioneer 35 (CP). These hybrid corn cultivars were selected as they are high-yielding varieties, are highly accepted by Indonesian farmers, and are resistant to lodging and downy mildew disease, which is one of the most destructive diseases of maize in humid subtropical and tropical regions of Asia [23]. Both cultivars had a harvest age of approximately 100 days [24]. The second factor (F) was the rate of the combination of MHA and $\mathrm{P}$ fertilizer: (1) the control with no MHA $\left(0 \mathrm{mg} \mathrm{kg}^{-1} \mathrm{MHA}\right)$ 
TABLE 1: Soil properties of the acidic soils of Sukosari, Tanggeran, and Karangsalam, Indonesia.

\begin{tabular}{|c|c|c|c|c|c|}
\hline Soil properties & Unit & Sukosari & Tanggeran & Karangsalam & Average \\
\hline Sand & $\mathrm{g} \mathrm{kg}^{-1}$ & 1.5 & 13.6 & 2.9 & 6.0 \\
\hline Silt & $\mathrm{g} \mathrm{kg}^{-1}$ & 6.6 & 31.7 & 8.7 & 15.7 \\
\hline Clay & $\mathrm{g} \mathrm{kg}^{-1}$ & 92 & 54.7 & 88.4 & 78.4 \\
\hline $\mathrm{pH} \mathrm{H}_{2} \mathrm{O}(1: 5)$ & & 4.6 & 5.2 & 5.2 & 5.0 \\
\hline CEC & $\mathrm{cmol}^{(+)} \mathrm{kg}^{-1}$ & 16.7 & 14.3 & 15.8 & 15.6 \\
\hline Exchangeable $\mathrm{K}$ & $\mathrm{cmol}^{(+)} \mathrm{kg}^{-1}$ & 0.60 & 0.31 & 0.36 & 0.42 \\
\hline Exchangeable $\mathrm{Na}$ & $\mathrm{cmol}^{(+)} \mathrm{kg}^{-1}$ & 0.004 & 0.01 & 0.02 & 0.01 \\
\hline Exchangeable $\mathrm{Ca}$ & $\mathrm{cmol}^{(+)} \mathrm{kg}^{-1}$ & 2.14 & 2.19 & 2.13 & 2.16 \\
\hline Exchangeable $\mathrm{Mg}$ & $\mathrm{cmol}^{(+)} \mathrm{kg}^{-1}$ & 0.47 & 1.03 & 1.24 & 0.91 \\
\hline Available P $\left(\right.$ Bray $\left.^{-1}\right)$ & $\mathrm{mg} \mathrm{kg}^{-1}$ & 1.9 & 2.2 & 1.1 & 1.8 \\
\hline Exchangeable $\mathrm{Al}$ & $\mathrm{cmol}^{(+)} \mathrm{kg}^{-1}$ & 1.2 & 0.5 & 0.5 & 0.73 \\
\hline
\end{tabular}

and no $\mathrm{P}$ fertilizer $\left(\mathrm{H}_{0} \mathrm{P}_{0}\right)$, (2) no $\mathrm{MHA}+\mathrm{P}$ fertilizer $\left(\mathrm{H}_{0} \mathrm{P}_{1}\right)$, (3) combined $35 \mathrm{mg} \mathrm{kg}-1 \mathrm{MHA}+\mathrm{P}$ fertilizer $\left(\mathrm{H}_{5} \mathrm{P}_{1}\right),(4)$ combined $75 \mathrm{mg} \mathrm{kg}^{-1} \mathrm{MHA}+\mathrm{P}$ fertilizer $\left(\mathrm{H}_{10} \mathrm{P}_{1}\right)$, and (5) combined $110 \mathrm{mg} \mathrm{kg}^{-1} \mathrm{MHA}+\mathrm{P}$ fertilizer $\left(\mathrm{H}_{15} \mathrm{P}_{1}\right)$. The amount of $\mathrm{P}$ fertilizer in each $\mathrm{P}_{1}$ treatment was equivalent to $120 \mathrm{mg} \mathrm{P}_{2} \mathrm{O}_{5} \mathrm{~kg}^{-1}$ air-dried soil. This combination of MHA and $\mathrm{P}$ fertilizer was applied within three periods of crop growth at 1,3, and $7 \mathrm{WAP}$, at a rate which was equivalent to $30 \%, 40 \%$, and $30 \%$ of the combined amount of MHA and P fertilizer, respectively. The CB and CP hybrid corn seeds were both cultivated in the three acidic soils each weighing $10 \mathrm{~kg}$, under air-dried conditions. They were placed in $35 \times 40 \mathrm{~cm}$ poly bags with distance intervals of $70 \times 30 \mathrm{~cm}$. There were 150 polybags consisting of 2 corn cultivars $\times 5$ treatment combinations of MHA and $\mathrm{P}$ fertilizer $\times 3$ soil sampling locations as blocks $\times 5$ replications.

2.4. Crop Growth Component and Crop Physiological Attribute Measurements. Three replications of the treated crops representing the three locations of acidic soils were selected to measure crop growth components at $7 \mathrm{WAP}$, which was coincident with the maximum vegetative growth of the crop. Crop growth components were measured in the aboveground plant part (crop height, number of leaves, and stem diameter) and the belowground plant part (root diameter, root dry weight, and root volume density). After measuring the aboveground components, the crop was harvested to measure its root attributes.

Another three replications of the treated crops representing the three locations of acidic soils were also selected for crop physiological attribute and root attribute measurements. The physiological attributes were chlorophyll content, stomatal aperture, photosynthetic rate, and nitrate reductase (NR) activity, which were measured at 7 and 10 WAP. In vivo NR activity was determined following the method described by Sudhakar et al. [25]. The crop photosynthetic rate was measured using a Photosynthetic Analyzer type LI Cor LI 6400. Chlorophyll was extracted in $80 \%$ acetone, and the absorbance was read at 663 and $645 \mathrm{~nm}$ in a UV-VIS spectrophotometer (UV Mini 1240 SHIMADZU) following the method described by Sudhakar et al. [25]. Stomatal aperture was measured following the method described by Eisele et al. [26]. Briefly, the image was captured using an OptiLab microscope camera, and stomatal apertures were measured in $\mu \mathrm{m}$ [27]. Then, the plants were harvested at 10 WAP to measure root attributes (root diameter, root dry weight, and root volume density).

2.5. Crop Yield Component Measurements. The crop yield components measured were total crop dry weight, grain dry weight, crop yield, $\mathrm{P}$ concentration in plant tissue, crop $\mathrm{P}$ uptake, and efficiency of crop $\mathrm{P}$ uptake. Total crop dry weight (in g plant ${ }^{-1}$ ) and grain dry weight (in g plant ${ }^{-1}$ ) were measured using the remaining nine replications representing the three locations of acidic soils at the harvest period (15 WAP), while crop yield (ton ha ${ }^{-1}$ ) was calculated based on grain yield $\left(\mathrm{g} \mathrm{plant}^{-1}\right) \times$ number of crops in 1 ha land with plant distance $70 \times 30 \mathrm{~cm}^{2}$. Crop leaves and grain were collected to measure the concentration of $\mathrm{P}$. The concentration of $\mathrm{P}$ in plant tissue was determined using the ammonium molybdate method after plant tissue was destroyed by nitric-perchloric acid wet digestion [28]. The crop P uptake in leaves and grain and efficiency of crop P uptake in leaves and grain was calculated as follows:

$\mathrm{P}$ uptake $\left(\mathrm{g} \mathrm{plant}^{-1}\right)=\mathrm{P}$ concentration in plant part $\times$ dry weight

Efficiency of $\mathrm{P}$ uptake $=(\mathrm{P}$ uptake of treatment $-\mathrm{P}$ uptake of control $) \times 100 \% /(\mathrm{P}$ uptake of treatment $)$

2.6. Statistical Analysis. Data were processed using Microsoft Excel for Mac version 16.37. All data obtained were subjected to analysis of variance (ANOVA) using the $\mathrm{R}$ project for statistical computing [29]. Differences between the treatment means were separated using Duncan's multiple range test at a $5 \%$ level of probability.

\section{Results}

3.1. Soil $p H$, Exchangeable Al, and Available P. Table 2 shows that the soils cultivated with the $\mathrm{CB}$ and $\mathrm{CP}$ corn cultivars had soil chemical characteristics that were not significantly different in their $\mathrm{pH} \mathrm{H}_{2} \mathrm{O}$, exchangeable $\mathrm{Al}$ content, and available P 15 WAP. The application of the MHA and P fertilizer at various rates did not significantly change the $\mathrm{pH}$ $\mathrm{H}_{2} \mathrm{O}$ value $15 \mathrm{WAP}$. The exchangeable $\mathrm{Al}$ content in the soil 15 WAP varied between the treatments. The highest value 
TABLE 2: Humic acid extracted from the composted manure (MHA) combined with phosphorus (P) fertilizer treatment effects on soil chemical properties 15 weeks after planting for two corn cultivars.

\begin{tabular}{|c|c|c|c|}
\hline Treatments & $\mathrm{pH} \mathrm{H} \mathrm{H}_{2} \mathrm{O}$ & Exchangeable aluminum $\left(\mathrm{cmol}^{(+)} \mathrm{kg}^{-1}\right)$ & Available $\mathrm{P}\left(\mathrm{mg} \mathrm{kg}^{-1}\right)$ \\
\hline \multicolumn{4}{|l|}{$C$ factor } \\
\hline $\mathrm{CB}$ & $5.45 \mathrm{q}$ & $0.63 \mathrm{q}$ & $3.63 \mathrm{q}$ \\
\hline $\mathrm{CP}$ & $5.42 \mathrm{q}$ & $0.83 \mathrm{q}$ & $2.52 \mathrm{q}$ \\
\hline \multicolumn{4}{|l|}{ F factor } \\
\hline $\mathrm{H}_{0} \mathrm{P}_{0}$ & $5.49 \mathrm{a}$ & $0.98 \mathrm{ab}$ & $1.22 \mathrm{~b}$ \\
\hline $\mathrm{H}_{0} \mathrm{P}_{1}$ & $5.26 \mathrm{a}$ & $0.56 \mathrm{ab}$ & $7.05 \mathrm{a}$ \\
\hline $\mathrm{H}_{5} \mathrm{P}_{1}$ & $5.40 \mathrm{a}$ & $1.11 \mathrm{a}$ & $3.18 \mathrm{ab}$ \\
\hline $\mathrm{H}_{10} \mathrm{P}_{1}$ & $5.28 \mathrm{a}$ & $0.88 \mathrm{ab}$ & $1.47 \mathrm{~b}$ \\
\hline $\mathrm{H}_{15} \mathrm{P}_{1}$ & $5.16 \mathrm{a}$ & $0.11 \mathrm{~b}$ & $2.46 \mathrm{ab}$ \\
\hline $\mathrm{C} \times \mathrm{F}$ & $(-)$ & $(-)$ & $(-)$ \\
\hline $\mathrm{CV}$ & 5.41 & 26.13 & 34.96 \\
\hline
\end{tabular}

$\mathrm{CV}$ is the coefficient of variation. $\mathrm{C}$ factor is the type of corn cultivar. $\mathrm{F}$ factor is a combination of MHA and P fertilizer. CB is Bisi 2 hybrid corn, $\mathrm{CP}$ is Pioneer 35 hybrid corn. $\mathrm{H}_{0} \mathrm{P}_{0}$ is the control, $\mathrm{H}_{0} \mathrm{P}_{1}$ is $0 \mathrm{mg} \mathrm{kg}-1$ MHA $+\mathrm{P}$ fertilizer, $\mathrm{H}_{5} \mathrm{P}_{1}$ is combined $35 \mathrm{mg} \mathrm{kg}^{-1} \mathrm{MHA}+\mathrm{P}$ fertilizer, $\mathrm{H}_{10} \mathrm{P}_{1}$ is combined $75 \mathrm{mg} \mathrm{kg}{ }^{-1}$ $\mathrm{MHA}+\mathrm{P}$ fertilizer, $\mathrm{H}_{15} \mathrm{P}_{1}$ is combined $110 \mathrm{mg} \mathrm{kg}{ }^{-1} \mathrm{MHA}+\mathrm{P}$ fertilizer. The rate of $\mathrm{P}$ fertilizer in each $\mathrm{P}_{1}$ treatment was equivalent to $120 \mathrm{mg}_{2} \mathrm{O}_{5} \mathrm{~kg}^{-1}$ airdried soil. Values followed by the same lowercase letter in a column were not significantly different based on Duncan's multiple range test at $p<0.05$. The results presented are the mean of 3 replicates.

for exchangeable $\mathrm{Al}$ content was found with the $\mathrm{H}_{5} \mathrm{P}_{1}$ treatment, but this value was not significantly different from those of the other treatments, except for $\mathrm{H}_{15} \mathrm{P}_{1}$, which had the lowest value. The soil available P 15 WAP showed significant differences in the values between the treatments. The highest available $\mathrm{P}$ content was found with the $\mathrm{H}_{0} \mathrm{P}_{1}$ treatment, whereas the lowest was found with the $\mathrm{H}_{10} \mathrm{P}_{1}$ and $\mathrm{H}_{0} \mathrm{P}_{0}$ treatments.

3.2. Crop Root Attributes. Figure 1 shows that the $\mathrm{CB}$ and $\mathrm{CP}$ cultivars had no significant differences in their crop root attributes, such as root diameter, root dry weight, or root volume density 7 and 10 WAP. No interactions were found between the cultivar factors and combined MHA and P fertilizer applications in terms of root diameter, root dry weight, and root volume density. The control treatment resulted in the lowest root diameter, root dry weight, and root volume density 7 and 10 WAP. The combined MHA and $\mathrm{P}$ treatments resulted in root diameter, root dry weight, and root volume densities that were not significantly different from $\mathrm{H}_{0} \mathrm{P}_{1} 7 \mathrm{WAP}$. However, the root diameter, root dry weight, and root volume density showed a positive response to the combined $\mathrm{MHA}$ and $\mathrm{P}$ treatment $10 \mathrm{WAP}$, where the greatest value was obtained in the $\mathrm{H}_{10} \mathrm{P}_{1}$ treatment.

3.3. $P$ Concentration, $P$ Uptake, and $P$ Uptake Efficiency. No significant differences were observed in the results for the $\mathrm{P}$ concentration, $\mathrm{P}$ uptake, and $\mathrm{P}$ uptake efficiency in the leaves and grains of the two cultivars 15 WAP (Table 3). Moreover, no interactions were found between the cultivars and MHA and P fertilizer applications for the P concentration, $\mathrm{P}$ uptake, and $\mathrm{P}$ uptake efficiency in the leaves and grains. The control treatment resulted in the lowest $\mathrm{P}$ concentration and uptake in the leaves and grains, whereas the combined MHA and P treatments could successfully increase $\mathrm{P}$ concentrations, $\mathrm{P}$ uptake, and $\mathrm{P}$ uptake efficiencies. The highest $\mathrm{P}$ concentrations in the leaves and grains were found with the $\mathrm{H}_{15} \mathrm{P}_{1}$ and $\mathrm{H}_{5} \mathrm{P}_{1}$ treatments, which, respectively, showed 1.9- and 4.6-fold increases, compared with the control. The highest efficiencies for the $\mathrm{P}$ uptake in the leaves and grains were found in the $\mathrm{H}_{10} \mathrm{P}_{1}$ and $\mathrm{H}_{5} \mathrm{P}_{1}$ treatments, respectively.

3.4. Chlorophyll Content and Stomatal Apertures. No significant differences were observed in the results for the chlorophyll content and stomatal apertures of the two cultivars 7 and 10 WAP (Figure 2). Moreover, no interactions were found between the cultivars and MHA and P applications in terms of chlorophyll content and stomatal aperture 7 and $10 \mathrm{WAP}$. The chlorophyll content in the MHA and P treatments was significantly higher than that of the control 7 and 10 WAP. However, there were no significant differences between the combined $\mathrm{MHA}$ and $\mathrm{P}$ treatments and $\mathrm{H}_{0} \mathrm{P}_{1}$. The stomatal apertures in $\mathrm{H}_{10} \mathrm{P}_{1}$ and $\mathrm{H}_{15} \mathrm{P}_{1}$ were significantly higher than those in the control, $\mathrm{H}_{0} \mathrm{P}_{1}$, and $\mathrm{H}_{5} \mathrm{P}_{1} 7$ WAP. No significant differences were found among the treatments in terms of stomatal aperture 10 WAP.

3.5. Photosynthesis Rate and NR Activity. No significant differences were observed for the results of the photosynthetic rate and NR activity for the two cultivars 7 and 10 WAP (Figure 3), nor were there interactions found between the cultivars and the MHA and P applications. A significant difference was found for the photosynthetic rate and NR activity between the MHA and P treatments and the control 7 WAP. The values of the photosynthetic rate and NR activity increased $10 \mathrm{WAP}$ after the MHA and $\mathrm{P}$ applications and the highest values were found in the $\mathrm{H}_{5} \mathrm{P}_{1}$ and $\mathrm{H}_{10} \mathrm{P}_{1}$ treatments, respectively.

3.6. Crop Height, Number of Leaves, and Stem Diameter. No significant differences were observed between the two cultivars in terms of crop height, stem diameter, and leaf number 7 WAP (Figure 4), nor were there any interactions found between the corn cultivars and the MHA applications. 


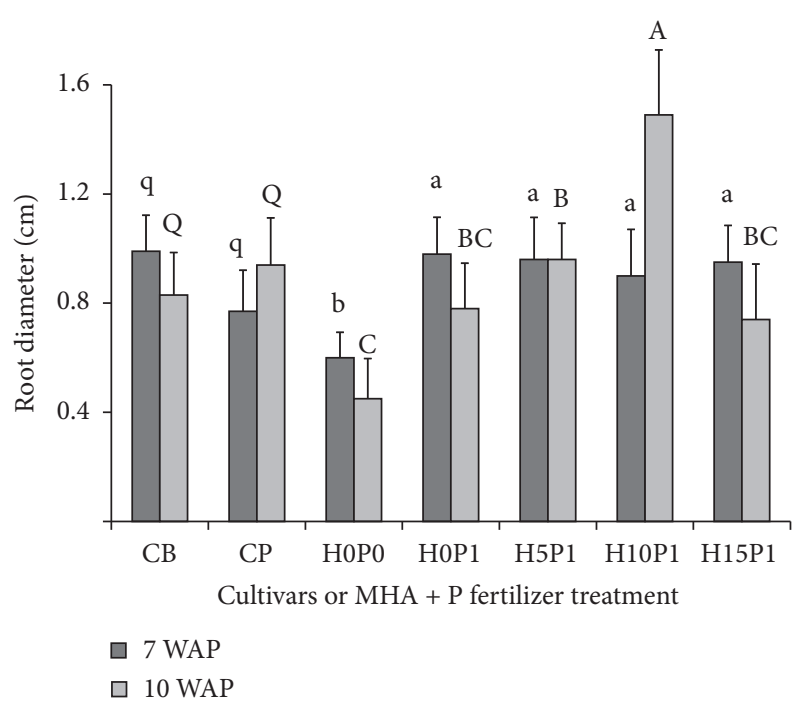

(a)

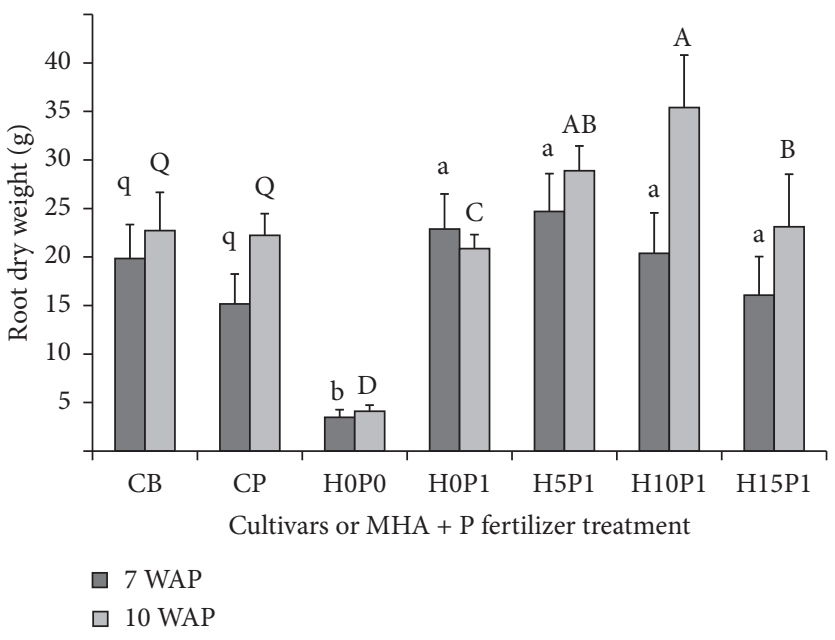

(b)

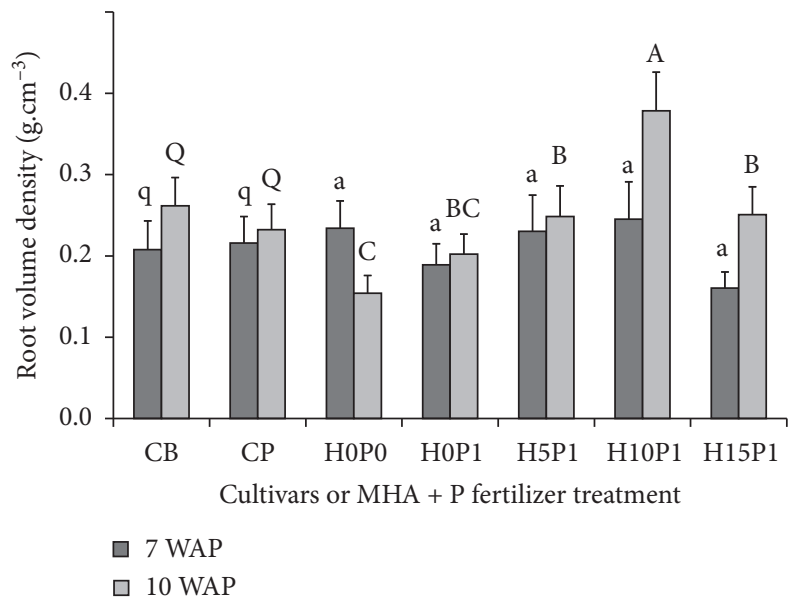

(c)

Figure 1: Root diameter (a), root dry weight (b), and root volume density (c) of corn 7 and 10 weeks after planting (WAP). CB is Bisi 2 hybrid corn, $\mathrm{CP}$ is Pioneer 35 hybrid corn. $\mathrm{H}_{0} \mathrm{P}_{0}$ is the control, $\mathrm{H}_{0} \mathrm{P}_{1}$ is $0 \mathrm{mg} \mathrm{kg}^{-1}$ composted manure (MHA) + $\mathrm{P}$ fertilizer, $\mathrm{H}_{5} \mathrm{P}_{1}$ is combined $35 \mathrm{mg} \mathrm{kg}^{-1} \mathrm{MHA}+\mathrm{P}$ fertilizer, $\mathrm{H}_{10} \mathrm{P}_{1}$ is combined $75 \mathrm{mg} \mathrm{kg}^{-1} \mathrm{MHA}+\mathrm{P}$ fertilizer, and $\mathrm{H}_{15} \mathrm{P}_{1}$ is combined $110 \mathrm{mg} \mathrm{kg} \mathrm{MHA}^{-1} \mathrm{P}$ fertilizer. The rate of $\mathrm{P}$ fertilizer in each $\mathrm{P}_{1}$ treatment was equivalent to $120 \mathrm{mg} \mathrm{P}_{2} \mathrm{O}_{5} \mathrm{~kg}^{-1}$ air-dried soil. Values followed by the same lowercase or uppercase letter were not significantly different based on Duncan's multiple range test at $p<0.05$. Results presented are the mean + standard error of 3 replicates.

Corn from the control treatments had lower values for crop height, number of leaves, and stem diameter. Furthermore, no significant differences were observed between the applications of the combined MHA and $\mathrm{P}$ and $\mathrm{H}_{0} \mathrm{P}_{1}$ in terms of corn height 7 WAP, except for the $\mathrm{H}_{15} \mathrm{P}_{1}$ treatment, which had lower significant results. The $\mathrm{H}_{10} \mathrm{P}_{1}$ treatment resulted in the highest values for the number of leaves and stem diameter. This $\mathrm{H}_{10} \mathrm{P}_{1}$ treatment was significantly higher compared to control and $\mathrm{H}_{15} \mathrm{P}_{1}$.

\subsection{Total Crop Dry Weight, Grain Dry Weight, and Corn Yield.} The results showed that the total crop dry weight, grain dry weight, and corn yields for the two cultivars were not significantly different (Figure 5), nor was there any interaction between the cultivars and the MHA and P treatments 15 WAP. This indicated that neither corn cultivar affected the increase in crop productivity caused by the applications of the MHA and P. The figures also showed that the total crop dry weight, grain dry weight, and corn yield were extremely low in the control treatment, indicating that without any improvements, the crops grown in acidic soils with low available $\mathrm{P}$ would be severely damaged. The $\mathrm{H}_{10} \mathrm{P}_{1}$ treatment produced the largest result in terms of total crop dry weight. In addition, it had a higher significant result in terms of grain dry weight and corn yield in comparison with the $\mathrm{H}_{0} \mathrm{P}_{1}$ and $\mathrm{H}_{15} \mathrm{P}_{1}$ treatments, but this result was not significantly different from that of $\mathrm{H}_{5} \mathrm{P}_{1}$.

\section{Discussion}

The results of this study indicate that the hybrid CB and CP cultivars can grow well after soil improvement with the 
TABLE 3: $\mathrm{P}$ concentrations in the crop tissues, crop uptake, and uptake efficiency in the two corn cultivars treated with humic acid extracted from the composted manure (MHA) and phosphorus (P) 15 weeks after planting.

\begin{tabular}{|c|c|c|c|c|c|c|}
\hline \multirow{2}{*}{ Treatments } & \multicolumn{2}{|c|}{$\mathrm{P}$ concentration $\left(\mathrm{g} \mathrm{kg}^{-1)}\right.$} & \multicolumn{2}{|c|}{$\mathrm{P}$ uptake $\left(\mathrm{g} \mathrm{plant}^{-1}\right)$} & \multicolumn{2}{|c|}{ P uptake efficiency (\%) } \\
\hline & Leaves & Grain & Leaves & Grain & Leaves & Grain \\
\hline \multicolumn{7}{|l|}{$C$ factor } \\
\hline $\mathrm{CB}$ & $2.6 \mathrm{r}$ & $3.0 \mathrm{q}$ & $0.07 \mathrm{q}$ & $0.25 \mathrm{q}$ & $10.3 \mathrm{q}$ & $39.2 \mathrm{q}$ \\
\hline $\mathrm{CP}$ & $2.1 \mathrm{q}$ & $3.0 \mathrm{q}$ & $0.06 \mathrm{q}$ & $0.27 \mathrm{q}$ & $9.1 \mathrm{q}$ & $42.1 \mathrm{q}$ \\
\hline \multicolumn{7}{|l|}{$F$ factor } \\
\hline H0P0 & $1.9 \mathrm{c}$ & $1.0 \mathrm{c}$ & $0.01 \mathrm{c}$ & $0.01 \mathrm{~d}$ & - & - \\
\hline H0P1 & $2.6 \mathrm{~b}$ & $3.4 \mathrm{~b}$ & $0.07 \mathrm{~b}$ & $0.27 \mathrm{c}$ & $8.4 \mathrm{~b}$ & $34.2 \mathrm{~b}$ \\
\hline H5P1 & $2.8 \mathrm{~b}$ & $4.1 \mathrm{a}$ & $0.07 \mathrm{~b}$ & $0.41 \mathrm{a}$ & $8.8 \mathrm{~b}$ & $51.5 \mathrm{a}$ \\
\hline H10P1 & $2.9 \mathrm{ab}$ & $3.4 \mathrm{~b}$ & $0.10 \mathrm{a}$ & $0.33 \mathrm{~b}$ & $11.8 \mathrm{a}$ & $41.3 \mathrm{~b}$ \\
\hline $\mathrm{H} 15 \mathrm{P} 1$ & $3.1 \mathrm{a}$ & $3.5 \mathrm{~b}$ & $0.08 \mathrm{ab}$ & $0.29 \mathrm{bc}$ & $9.8 \mathrm{~b}$ & $35.7 \mathrm{~b}$ \\
\hline $\mathrm{CxF}$ & $(-)$ & $(-)$ & $(-)$ & $(-)$ & $(-)$ & $(-)$ \\
\hline $\mathrm{CV}$ & 24.8 & 33.4 & 30.9 & 30.6 & 28 & 27 \\
\hline
\end{tabular}

$\mathrm{P}$ uptake $\left(\mathrm{g}\right.$ plant $\left.{ }^{-1}\right)=\mathrm{P}$ concentration in plant part $\times$ dry weight. Efficiency of $\mathrm{P}$ uptake $=(\mathrm{P}$ uptake of treatment $-\mathrm{P}$ uptake of control $) \times 100 \% /(\mathrm{P}$ uptake of treatment). CV is the coefficient of variation. C factor is the type of corn cultivar. $\mathrm{F}$ factor is a combination of MHA and P fertilizer. CB is Bisi 2 hybrid corn, $\mathrm{CP}$ is Pioneer 35 hybrid corn. $\mathrm{H}_{0} \mathrm{P}_{0}$ is the control, $\mathrm{H}_{0} \mathrm{P}_{1}$ is $0 \mathrm{mg} \mathrm{kg}^{-1} \mathrm{MHA}+\mathrm{P}$ fertilizer, $\mathrm{H} 5 \mathrm{P} 1$ is combined $35 \mathrm{mg} \mathrm{kg}^{-1} \mathrm{MHA}+\mathrm{P}$ fertilizer, $\mathrm{H}_{10} \mathrm{P}_{1}$ is combined $75 \mathrm{mg} \mathrm{kg}^{-1}$ MHA + P fertilizer, and $\mathrm{H}_{15} \mathrm{P}_{1}$ is combined $110 \mathrm{mg} \mathrm{kg}^{-1} \mathrm{MHA}+\mathrm{P}$ fertilizer. The rate of $\mathrm{P}$ fertilizer in each $\mathrm{P}_{1}$ treatment was equivalent to $120 \mathrm{mg}$ $\mathrm{P}_{2} \mathrm{O}_{5} \mathrm{~kg}^{-1}$ air-dried soil. Values followed by the same lowercase letter in a column were not significantly different based on Duncan's multiple range test at $p<0.05$. The results presented are the mean of 9 replicates.

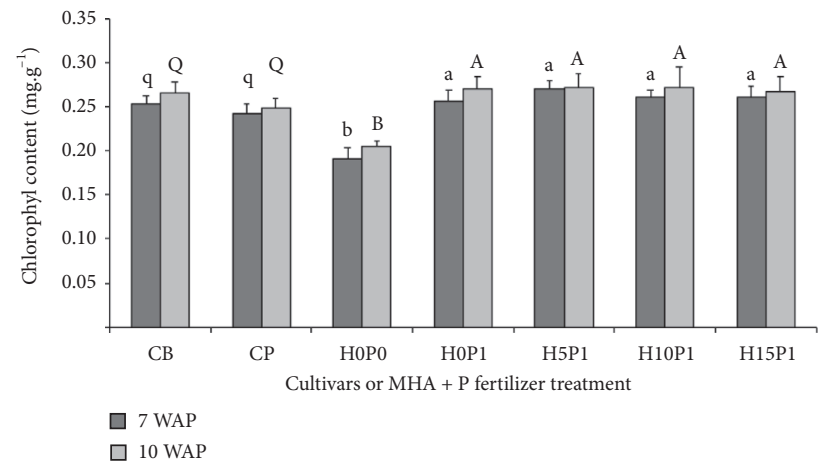

(a)

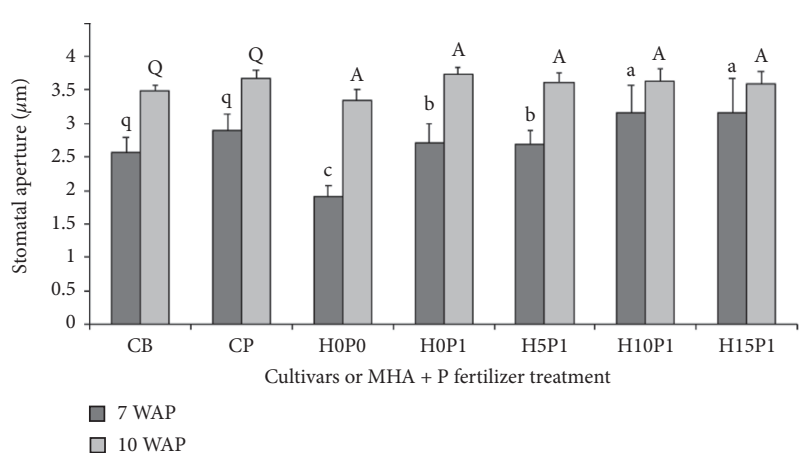

(b)

Figure 2: Chlorophyll content (a) and stomatal apertures (b) of corn 7 and 10 weeks after planting (WAP). CB is Bisi 2 hybrid corn, CP is Pioneer 35 hybrid corn. $\mathrm{H}_{0} \mathrm{P}_{0}$ is the control, $\mathrm{H}_{0} \mathrm{P}_{1}$ is $0 \mathrm{mg} \mathrm{kg}{ }^{-1}$ composted manure (MHA) $+\mathrm{P}$ fertilizer, $\mathrm{H}_{5} \mathrm{P}_{1}$ is combined $35 \mathrm{mg}$ kg $\mathrm{MHA}+\mathrm{P}$ fertilizer, $\mathrm{H}_{10} \mathrm{P}_{1}$ is combined $75 \mathrm{mg} \mathrm{kg}^{-1} \mathrm{MHA}+\mathrm{P}$ fertilizer, and $\mathrm{H}_{15} \mathrm{P}_{1}$ is combined $110 \mathrm{mg} \mathrm{kg}^{-1} \mathrm{MHA}+\mathrm{P}$ fertilizer. The rate of $\mathrm{P}$ fertilizer in each $\mathrm{P}_{1}$ treatment was equivalent to $120 \mathrm{mg} \mathrm{P}_{2} \mathrm{O}_{5} \mathrm{~kg}^{-1}$ air-dried soil. Values followed by the same lowercase or uppercase letter in a column were not significantly different based on Duncan's multiple range test at $p<0.05$. The results presented are the mean + standard error of 3 replicates.

addition of MHA and P and that both could be planted in acidic soils that suffer from soil acidity and low $\mathrm{P}$ availability. Although both cultivars showed an extremely low growth and yield when not treated with MHA and P fertilizers (control), both showed substantial responses with the combined MHA and P fertilizer applications and were not significantly different in terms of the various parameters assessed, namely, root development, $\mathrm{P}$ uptake, chlorophyll content, stomatal aperture, photosynthetic rate, NR activity, total crop dry weight, grain dry weight, and corn yield.

Crops are suspected to influence the interactions that occur among MHA, soil available $\mathrm{P}$, and soil exchangeable Al. Our results showed that the soil available $\mathrm{P}$ was lower with the combined MHA and $\mathrm{P}$ treatments compared with $\mathrm{P}$ treatment alone $\left(\mathrm{H}_{0} \mathrm{P}_{1}\right)$. In this study, soil exchangeable $\mathrm{Al}$ and available $\mathrm{P}$ changed after the soils were treated with
MHA and $\mathrm{P}$, whereas soil $\mathrm{pH}$ was not affected. Humic acid is an organic acid that has a positive interaction with $\mathrm{P}$ availability in the soil; thus, $\mathrm{P}$ availability in soil solutions and $\mathrm{P}$ concentration in crops increased [30]. When $100 \mathrm{mg} \mathrm{kg}^{-1} \mathrm{C}$-humic acid was applied after adding $\mathrm{P}$, soil available $\mathrm{P}$ extracted via mixed ionic resin exchange increased by $19 \%$ relative to the control [8]. The inhibition of $\mathrm{P}$ adsorption by the presence of humic compounds is attributed to the competitive effect of $\mathrm{OH}$ and $\mathrm{COOH}$ groups and the prevention of $\mathrm{P}$ adsorption by electric fields around the adsorbed humic acid molecules [31]. When present, these functional groups in MHA are effective at preventing the adsorption of $\mathrm{P}$ by soil components. The content of exchangeable $\mathrm{Al}$ was not in line with changes in the rate of MHA and P 15 WAP. In addition to promoting the increase in the availability of $\mathrm{P}$ for crops, the application of combined 


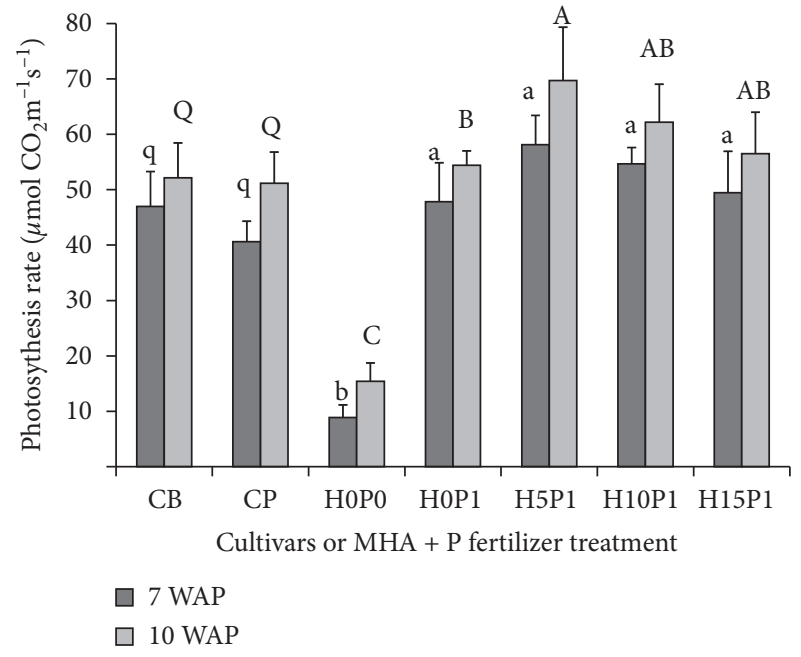

(a)

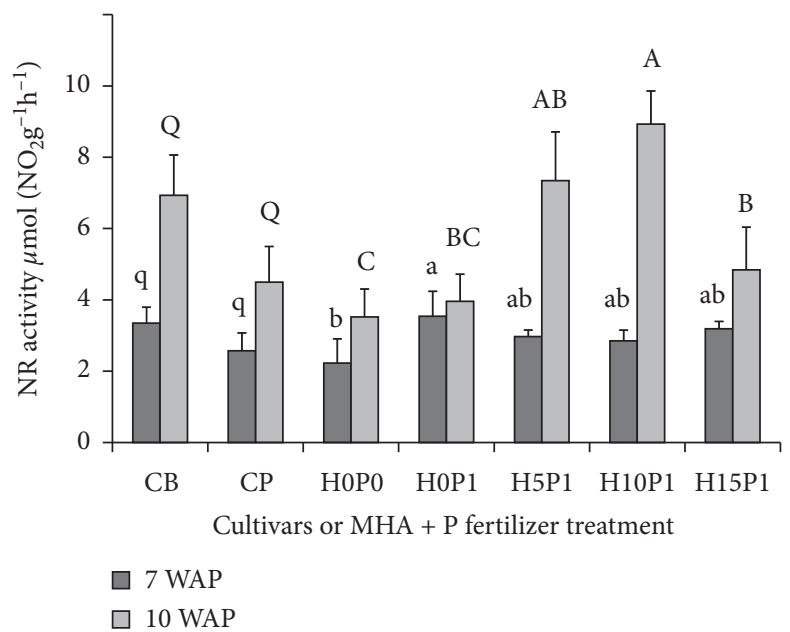

(b)

Figure 3: Photosynthesis rate (a) and nitrate reductase (NR) activity (b) of corn at 7 and 10 weeks after planting (WAP). CB is Bisi 2 hybrid corn, CP is Pioneer 35 hybrid corn. $\mathrm{H}_{0} \mathrm{P}_{0}$ is the control, $\mathrm{H}_{0} \mathrm{P}_{1}$ is $0 \mathrm{mg} \mathrm{kg}^{-1}$ composted manure $(\mathrm{MHA})+\mathrm{P}$ fertilizer, $\mathrm{H}_{5} \mathrm{P}_{1}$ is combined $35 \mathrm{mg} \mathrm{kg}^{-1} \mathrm{MHA}+\mathrm{P}$ fertilizer, $\mathrm{H}_{10} \mathrm{P}_{1}$ is combined $75 \mathrm{mg} \mathrm{kg}^{-1} \mathrm{MHA}+\mathrm{P}$ fertilizer, and $\mathrm{H}_{15} \mathrm{P}_{1}$ is combined $110 \mathrm{mg} \mathrm{kg} \mathrm{MHA}^{-1} \mathrm{P}$ fertilizer. The rate of $\mathrm{P}$ fertilizer in each $\mathrm{P}_{1}$ treatment was equivalent to $120 \mathrm{mg} \mathrm{P}_{2} \mathrm{O}_{5} \mathrm{~kg}^{-1}$ air-dried soil. Values followed by the same lowercase or uppercase letter in a column were not significantly different based on Duncan's multiple range test at $p<0.05$. The results presented are the mean + standard error of 3 replicates.

MHA and P fertilizer seemed to overcome the negative effects of $\mathrm{Al}$ availability in the soil on crops.

Some previous research has demonstrated that humic acid causes environmental improvements in the crop rhizosphere through three mechanisms. (1) The first mechanism is attenuating the toxic influence of exchangeable $\mathrm{Al}$ on the roots by humic acid. Humic acid neutralizes the toxic effects of exchangeable $\mathrm{Al}$ on root growth and promotes nutrient uptake by roots in broad bean (Vicia faba L.) crops [32]. The task of humic acid is assisted by soil properties, particularly CEC, which can possibly absorb $\mathrm{Al}$ ions when the ions are released by soil components. (2) The second mechanism is increasing the deposition of corn root exudates, thus improving the enzyme activity in the rhizosphere. The enzymatic activity of phosphatase, which was capable of hydrolyzing organic $\mathrm{P}$ compounds to available $\mathrm{P}$, could be detected in the humic extracts from the manure and casting [33]. In line with this, the addition of humic acid to the soil also increases the transformation of organic $\mathrm{P}$ from a resistant to an unstable form, thereby increasing the $\mathrm{P}$ available in the soil [34]. (3) The third mechanism is quickening the process of $\mathrm{P}$ diffusion in the soil, thereby increasing $\mathrm{P}$ diffusion in the soil [35], and $\mathrm{P}$ fixation on acidic soils slows down the $\mathrm{P}$ diffusion process in the rhizosphere. Thus, the uptake of $\mathrm{P}$ depends only on root growth, which occurs slowly. However, these three mechanisms of crop rhizosphere improvement due to the addition of humic acid cannot be causally related to the improvement of root attributes and nutrient absorption by the crops.

Crop roots have a major role in the absorption mechanisms of nutrients from soils and the transport of nutrients in crops. The presence of exchangeable aluminum in the soil has a direct negative effect on crop roots; therefore, the binding of $\mathrm{Al}$ to the walls of outer cells produces apoplastic lesions, which may increase the rigidity of the elongation zones of roots, expand the inhibitory cell wall, and cause cells to rupture [36]. In such rooting conditions, it will certainly cause a decrease in the ability of roots to absorb nutrients and water from the soil. Fortunately, the crop roots of both corn cultivars developed well in the combined MHA and P fertilizer treatments. Canellas et al. [37] reported that humic acid promotes the increase of plasma membrane $\mathrm{H}^{+}$-ATPase activity, therefore, (1) acidifying the apoplast and loosening the cell wall which allows for the elongation of root cells and improves the surface of the root area, and (2) increasing the electrochemical proton gradient that drives ion transport across the cell membranes, thereby improving nutrient absorption. This mechanism is thought to explain the substantial increase in root growth $10 \mathrm{WAP}$ and the $\mathrm{P}$ uptake 15 WAP, in both corn cultivars treated with the MHA and P combination. The combined treatment not only increased the physical root size, such as the root diameter and root dry weight, but also increased the root volume density. The $\mathrm{H}_{10} \mathrm{P}_{1}$ treatment improved the crop root attributes of the two cultivars with the most value, followed by the $\mathrm{H}_{5} \mathrm{P}_{1}$ treatment. The $\mathrm{H}_{10} \mathrm{P}_{1}$ treatment increased root diameter, root volume density, and dry root weight by 1.9-, 1.9-, and 1.7fold $10 \mathrm{WAP}$, respectively, compared with $\mathrm{H}_{0} \mathrm{P}_{1}$. In addition, in this study, both corn cultivars were planted in soil and the MHA was given three times through the soil at 1, 3, and 7 WAP, while previously Canellas et al. [37] were limited to the analysis of corn seed roots that were planted for 7 days in humic acid solution from vermicompost. We suspect that the addition of MHA to the acidic soils with problematic $\mathrm{P}$ 


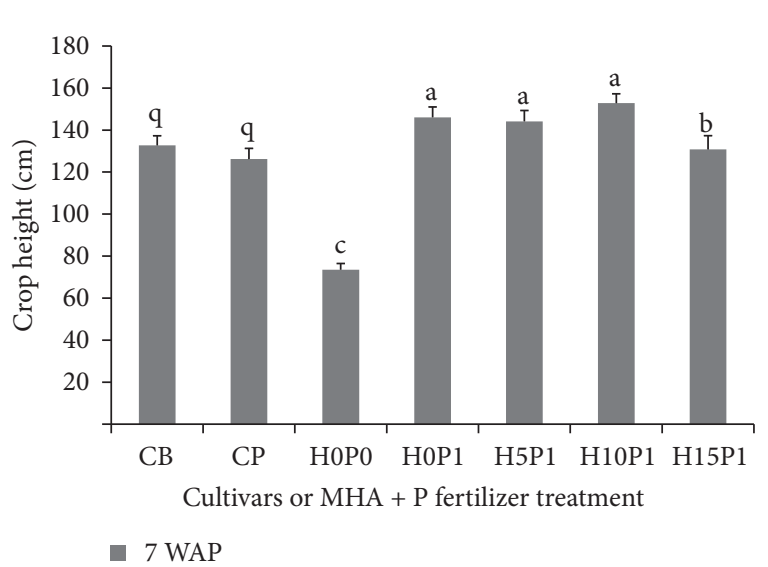

(a)

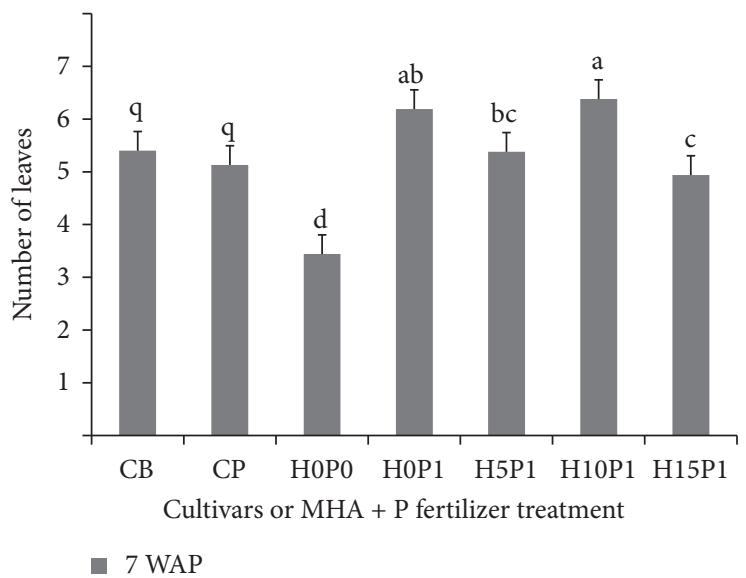

(b)

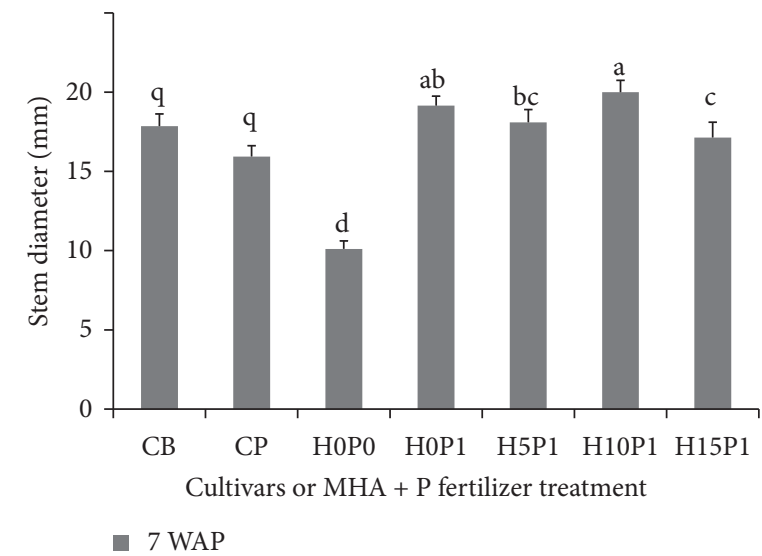

(c)

Figure 4: Crop height (a), number of leaves (b), and stem diameter (c) 7 weeks after planting (WAP). CB is Bisi 2 hybrid corn, CP is Pioneer 35 hybrid corn. $\mathrm{H}_{0} \mathrm{P}_{0}$ is the control, $\mathrm{H}_{0} \mathrm{P}_{1}$ is $0 \mathrm{mg} \mathrm{kg}^{-1}$ composted manure $(\mathrm{MHA})+\mathrm{P}$ fertilizer, $\mathrm{H}_{5} \mathrm{P}_{1}$ is combined $35 \mathrm{mg}$ kg ${ }^{-1} \mathrm{MHA}+\mathrm{P}$ fertilizer, $\mathrm{H}_{10} \mathrm{P}_{1}$ is combined $75 \mathrm{mg} \mathrm{kg}^{-1} \mathrm{MHA}+\mathrm{P}$ fertilizer, and $\mathrm{H}_{15} \mathrm{P}_{1}$ is combined $110 \mathrm{mg} \mathrm{kg}^{-1} \mathrm{MHA}+\mathrm{P}$ fertilizer. The rate of $\mathrm{P}$ fertilizer in each $\mathrm{P}_{1}$ treatment was equivalent to $120 \mathrm{mg} \mathrm{P}_{2} \mathrm{O}_{5} \mathrm{~kg}^{-1}$ air-dried soil. Values followed by the same lowercase letter in a column were not significantly different based on Duncan's multiple range test at $p<0.05$. The results presented are the mean + standard error of 3 replicates.

improved the rhizospheres of the crops and resulted in more effective rooting so that the vegetative growth of the crops was maintained until harvest.

There was an improvement of the root attributes in both cultivars of corn, and an increase in $\mathrm{P}$ uptake and $\mathrm{P}$ uptake efficiency in their leaves and grains after the $\mathrm{H}_{5} \mathrm{P}_{1}$ and $\mathrm{H}_{10} \mathrm{P}_{1}$ treatments. Compared with the control, the $\mathrm{H}_{0} \mathrm{P}_{1}$ treatment also increased $\mathrm{P}$ uptake and $\mathrm{P}$ uptake efficiency; however, the increment remained lower than the increases in $\mathrm{P}$ uptake and $\mathrm{P}$ uptake efficiency in the combined MHA and $\mathrm{P}$ treatments. The MHA in the $\mathrm{H}_{5} \mathrm{P}_{1}$ and $\mathrm{H}_{10} \mathrm{P}_{1}$ treatments led to an increase in both $\mathrm{P}$ uptake and $\mathrm{P}$ absorption efficiency 1.4 and 1.5 times greater than the treatments that were only given $\mathrm{P}$ but without $\mathrm{MHA}\left(\mathrm{H}_{0} \mathrm{P}_{1}\right)$. This improvement of the crop root attributes and crop nutrient uptake subsequently explains the improvement in the production of dry matter and corn yield of the two cultivars.

The nutrient status in the crop canopy cannot be disconnected from the growth of the crop parts in the soil. In the control treatment, restricted root development was followed by low crop growth and crop yields. A lesser amount of dry matter was translocated to the upper crop parts in the unfertilized crops compared with the fertilized ones [38]. Increased uptake of $\mathrm{P}$ in the leaves and grains in both cultivars after being treated with combined MHA and P is an indication of an increase in the process of the translocation of dry matter to the upper part of the crop. Compared with the crop height, the number of leaves, and the stem diameter of the control treatments, those from the $\mathrm{H}_{10} \mathrm{P}_{1}$ treatment 7 WAP were increased 2.1-, 1.9-, and 2.0fold, respectively, indicating the success of the $\mathrm{H}_{10} \mathrm{P}_{1}$ treatment to ensure improved crop growth. The $\mathrm{H}_{5} \mathrm{P}_{1}$ and $\mathrm{H}_{10} \mathrm{P}_{1}$ treatments 15 WAP increased the grain dry weight and corn yields, and the values were remarkably higher in comparison with the $\mathrm{H}_{0} \mathrm{P}_{1}$ treatment. The dry weight and corn yields produced by the $\mathrm{H}_{5} \mathrm{P}_{1}$ and $\mathrm{H}_{10} \mathrm{P}_{1}$ treatments were 1.2 and 1.3 times higher compared to the $\mathrm{H}_{0} \mathrm{P}_{1}$ treatments 15 WAP. This indicates that the addition of the MHA combined with the $\mathrm{P}$ causes crop yields that are superior to crops that are only given $\mathrm{P}$ fertilizer. In the $\mathrm{H}_{5} \mathrm{P}_{1}$ treatment, the MHA 


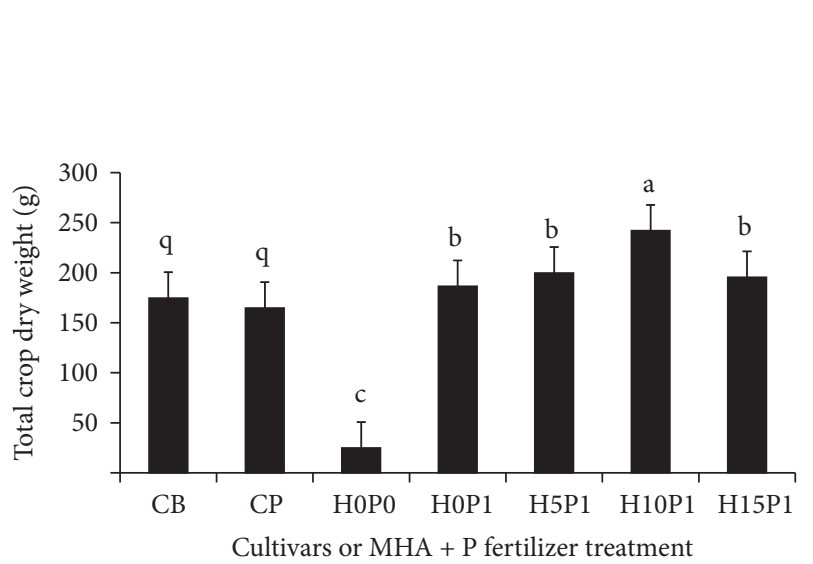

15 WAP

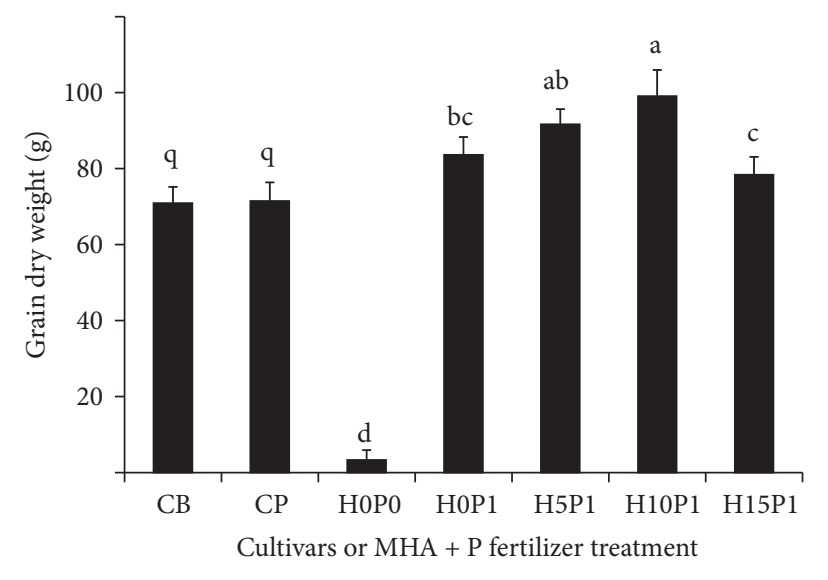

15 WAP

(b) (a)

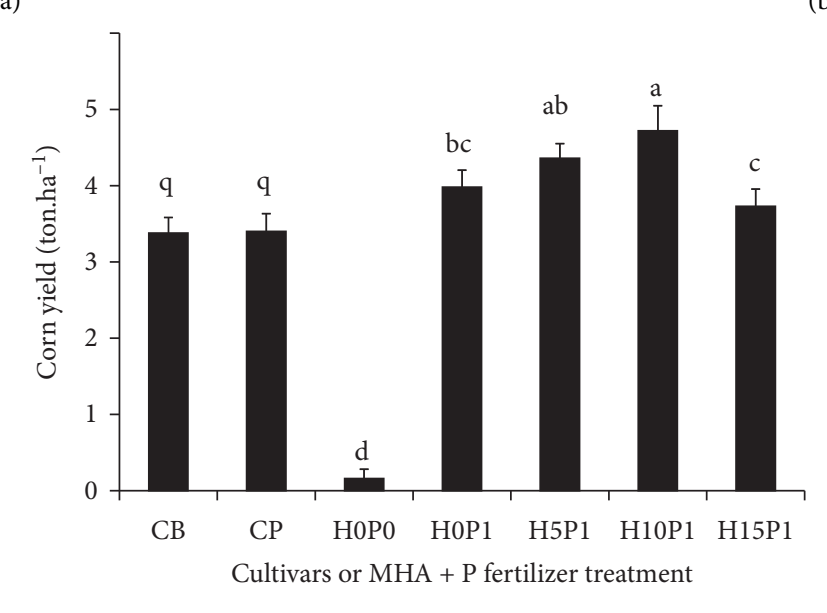

15 WAP

(c)

Figure 5: Total crop dry weight (a), grain dry weight (b), and corn yield (c) at 15 weeks after planting (WAP). CB is Bisi 2 hybrid corn, CP is Pioneer 35 hybrid corn. $\mathrm{H}_{0} \mathrm{P}_{0}$ is the control, $\mathrm{H}_{0} \mathrm{P}_{1}$ is $0 \mathrm{mg} \mathrm{kg}^{-1}$ composted manure (MHA) $+\mathrm{P}$ fertilizer, $\mathrm{H}_{5} \mathrm{P}_{1}$ is combined 35 mg kg $\mathrm{MHA}+\mathrm{P}$ fertilizer, $\mathrm{H}_{10} \mathrm{P}_{1}$ is combined $75 \mathrm{mg} \mathrm{kg}^{-1} \mathrm{MHA}+\mathrm{P}$ fertilizer, and $\mathrm{H}_{15} \mathrm{P}_{1}$ is combined $110 \mathrm{mg} \mathrm{kg}^{-1} \mathrm{MHA}+\mathrm{P}$ fertilizer. The rate of $\mathrm{P}$ fertilizer in each $\mathrm{P}_{1}$ treatment was equivalent to $120 \mathrm{mg} \mathrm{P}_{2} \mathrm{O}_{5} \mathrm{~kg}^{-1}$ air-dried soil. Values followed by the same lowercase letter in a column were not significantly different based on Duncan's multiple range test at $p<0.05$. The results presented are the mean + standard error of 9 replicates.

was applied at a low rate of $35 \mathrm{mg} \mathrm{kg}^{-1}$, which was lower than the recommended rate by Sharif et al. [7] who used humic material from lignitic coal in alkaline soils.

The chlorophyll contents from the $\mathrm{CB}$ and $\mathrm{CP}$ cultivars were considerably enhanced by the $\mathrm{H}_{0} \mathrm{P}_{1}$ treatment and MHA combined with $\mathrm{P}$ at 7 and 10 WAP, whereas the addition of MHA in the $\mathrm{H}_{5} \mathrm{P}_{1}, \mathrm{H}_{10} \mathrm{P}_{1}$, and $\mathrm{H}_{15} \mathrm{P}_{1}$ treatments did not increase the leaf chlorophyll content. This means that the increase in leaf chlorophyll content in the $\mathrm{H}_{0} \mathrm{P}_{1}, \mathrm{H}_{5} \mathrm{P}_{1}$, $\mathrm{H}_{10} \mathrm{P}_{1}$, and $\mathrm{H}_{15} \mathrm{P}_{1}$ treatments was due to $\mathrm{P}$ application. Bijanzadeh et al. [18] reported that foliar application of humic acid combined with salicylic acid improved the chlorophyll content of corn seedlings. However, reports on the relationship between chlorophyll content and foliar applications of humic acid did not report uniform results. Maibodi et al. [39] showed that leaf chlorophyll content was not affected by foliar application of commercial humic acid.
Thus, the differences in the results of the present study with those of Bijanzadeh et al. [18] were not caused by differences in the method of administration of humic acid, which in the present study was provided by the soil. Bijanzadeh et al. [18] related their results to drought stress causing crop cell membrane deterioration associated with increased electrolyte leakage and a decreased membrane stability index. However, Maibodi et al. [39] showed that crops do not experience certain environmental stresses. Thus, the response of increased crop chlorophyll content to humic acid is likely to occur when the crop experiences specific environmental stresses that cause cell membrane deterioration in the upper part of the crop.

The stomatal aperture of the $\mathrm{H}_{10} \mathrm{P}_{1}$ treatment showed the highest value among the other treatments 7 WAP. The results of this study indicate that MHA given through the soil can increase the stomatal aperture. Even in soils that suffer 
from acidity stress and low $\mathrm{P}$ availability, the MHA combined with the $\mathrm{P}$ treatment does not only play a role in neutralizing the negative effects of these soil constraints but could also improve the physiological performance of the crops. Endogenous plant hormones stimulate stomatal apertures and development in crop leaves [40], and humic acid has a very beneficial role that directly activates crop signaling pathways related to plant hormonal action [41]. The MHA and $\mathrm{P}$ treatments that were given at 1,3 , and $7 \mathrm{WAP}$ are thought to be effective at activating the plant hormones that control the stomatal apertures from the beginning of crop growth. Conversely, the control and $\mathrm{H}_{0} \mathrm{P}_{1}$ treatments inhibited the activation of the plant hormones that stimulate stomatal apertures. Ten WAP, there were no significant differences between the stomatal apertures in the control and $\mathrm{H}_{0} \mathrm{P}_{1}$ with the MHA and $\mathrm{P}$ combined treatments. In this case, the plant hormones were not the only factor affecting the stomatal apertures. Environmental cues provided by the light intensity and concentrations of atmospheric carbon dioxide also affected the stomatal apertures and development [40]. Increased rates of nutrient uptake by the crops due to the addition of humic acid may contribute to not only crop rhizosphere amendments and the physical improvement of crop roots but also the enhancement of the role of the plant hormones whose work is driven directly by the humic acid. On the other hand, aspects of the sensitivity of plant hormones in acidic soils and the effectiveness of the roles of humic acid in activating plant hormones in these environments need to be investigated further.

Stomatal apertures are crucial for determining crop photosynthesis performance, water use efficiency, and crop yields [40]. The results from the treatments combining the MHA with $\mathrm{P}$ on the photosynthetic rate and NR reductase were in accordance with the treatment influence on the stomatal aperture. The combined treatments had better photosynthetic rates than the controls and $\mathrm{H}_{0} \mathrm{P}_{1} 10$ WAP. However, the combined treatments did not result in a significant difference in the photosynthetic rate at 7 WAP. MHA combined with $\mathrm{P}$ treatment increased the photosynthetic rate by 1.04-1.3 times in comparison with the $\mathrm{H}_{0} \mathrm{P}_{1}$ treatment and by 3.5-4.3 times in comparison with the control, respectively. The data shows that although the photosynthetic rate increased after the $\mathrm{P}$ treatment alone, a higher increase occurred after being treated with the MHA and $\mathrm{P}$ combination. Lotfi et al. [42] have also shown that net crop photosynthesis is also improved by foliar application of humic acid. The increase in photosynthetic rate is in line with the increase in the efficiency of $\mathrm{P}$ uptake, and because the stomatal aperture can also increase photosynthetic rate through its effect on the plant hormone, it can be said that the plant hormone also indirectly influences the photosynthetic rate.

The increase in NR activity is also in line with the increased efficiency of crop $\mathrm{P}$ uptake. Nitrate reductase is the enzyme that catalyzed the process of reducing nitrate $\mathrm{N}$ to organic forms in crops. With increases in $\mathrm{N}_{-} \mathrm{NO}_{3}{ }^{-}$supplies to crops, the NR activity is increased, as the presence of the $\mathrm{N}-\mathrm{NO}_{3}{ }^{-}$in the crops is a positive regulator of this enzyme [43]. The application of $\mathrm{P}$ can also increase NR activity and the photosynthetic rate of crops grown on soil that lack $\mathrm{P}$. The MHA combined with $\mathrm{P}$ had better NR activities than the controls and $\mathrm{H}_{0} \mathrm{P}_{1} 10 \mathrm{WAP}$, which corresponds with the results of Nardi et al. [44], who reported that the humus extracted from the soil gives the highest increase in NR activity. MHA and $\mathrm{P}$ combined treatments did not show a significant difference in NR activity 7 WAP. The MHA and P treatments increased NR activity by 1.4-2.2 times in comparison with the $\mathrm{H}_{0} \mathrm{P}_{1}$ treatment and by 1.2-2.2 times in comparison with the control. These data indicate that although the NR activity increased after the P treatment alone, a higher increase occurred after being treated with the MHA combined with $\mathrm{P}$.

The results clearly indicate that MHA combined with $\mathrm{P}$ was capable of increasing the crop P uptake and enhancing the crop physiological performance in the form of stomatal aperture, photosynthetic rate, and NR activity. MHA when combined with $\mathrm{P}$ is proven to greatly contribute to increasing the total crop dry weight, grain dry weight, and crop yields in the $\mathrm{CB}$ and $\mathrm{CP}$ cultivars in soils with acidity problems and low $\mathrm{P}$ availability. This means that MHA could be used to ameliorate acid soils with a very significant impact on the growth and yields of corn. It could also mitigate the effects of global change that may result from the extensive use of lignitic coal-or leonardite-extracted humic acid as unrenewable natural $\mathrm{C}$ materials.

\section{Conclusions}

The substantial increase in the crop yields for both cultivars of corn planted in acidic areas with low $\mathrm{P}$ availabilities, due to the combined MHA and P treatments, was not limited to the improvement of the crop rhizosphere, which in this case attenuated the aluminum toxicity and increased the soil available $\mathrm{P}$. The treatments also resulted in a remarkable increase in the crop root dimensions, boosting the crop $\mathrm{P}$ uptake, followed by a significant improvement of the crops physiological performance in the form of the stomatal aperture, photosynthetic rate, and NR activity. The best rate, which is equal to the rate obtained from the $\mathrm{P}$ fertilizer combined with a low rate of MHA at $75 \mathrm{mg} \mathrm{kg}^{-1}$, was obtained with the $\mathrm{H}_{10} \mathrm{P}_{1}$ treatment.

\section{Data Availability}

The data used to support the findings of this study are available on request from Benito Heru Purwanto (benito@ ugm.ac.id; +62274548814).

\section{Conflicts of Interest}

The authors declare that there are no conflicts of interest regarding the publication of this paper.

\section{Acknowledgments}

This work was supported by the "Hibah Penelitian Unggulan Universitas Gadjah Mada" under grant number 727/ UN1-P.III/LT/DIT-LIT/2016. 


\section{References}

[1] D. K. Ray, N. D. Mueller, P. C. West, and J. A. Foley, "Yield trends are insufficient to double global crop production by 2050," PLoS One, vol. 8, no. 6, Article ID e66428, 2013.

[2] FAO, World Agriculture: Towards 2015/2030 Summary Report, FAO, Rome, Italy, 2002.

[3] L. N. Tandzi, C. S. Mutengwa, E. L. M. Ngonkeu, and V. Gracen, "Breeding maize for tolerance to acidic soils: a review," Agronomy, vol. 8, no. 6, pp. 1-21, 2018.

[4] A. Sanli, T. Karadogan, and M. Tonguc, "Effects of leonardite applications on yield and some quality parameters of potatoes (Solatium tuberosum L.)," Turkish Journal of Field Crops, vol. 18, no. 1, pp. 20-26, 2013.

[5] M. M. Tahir, M. Khurshid, M. Z. Khan, M. K. Abbasi, and M. H. Kazmi, "Lignite-derived humic acid effect on growth of wheat plants in different soils," Pedosphere, vol. 21, no. 1, pp. 124-131, 2011.

[6] K. M. Cimrin and I. Yilmaz, "Humic acid applications to lettuce do not improve yield but do improve phosphorus availability," Acta Agriculturae Scandinavica, Section B-Soil \& Plant Science, vol. 55, no. 1, pp. 58-63, 2005.

[7] M. Sharif, R. A. Khattak, and M. S. Sarir, "Effect of different levels of lignitic coal derived humic acid on growth of maize plants," Communications in Soil Science and Plant Analysis, vol. 33, no. 19-20, pp. 3567-3580, 2002.

[8] S. D. Rosa, C. A. Silva, and H. J. G. M. Maluf, "Phosphorus availability and soybean growth in contrasting oxisols in response to humic acid concentrations combined with phosphate sources," Archives of Agronomy and Soil Science, vol. 66, no. 2, pp. 220-235, 2020.

[9] N. S. Barot and H. K. Bagla, "Extraction of humic acid from biological matrix - dry cow dung powder," Green Chemistry Letters and Reviews, vol. 2, no. 4, pp. 217-221, 2009.

[10] J. Alferai, P. Rovira, F. Alsewailem et al., "Uncomposted sheep and cow manures as a source of commercial humic amendments: an exploratory study," Communications in Soil Science and Plant Analysis, vol. 46, no. 9, pp. 1137-1156, 2015.

[11] Z. Zhang, Y. Zhao, T. Yang et al., "Effects of exogenous protein-like precursors on humification process during lignocellulose-like biomass composting: amino acids as the key linker to promote humification process," Bioresource Technology, vol. 291, Article ID 121882, 2019.

[12] X. Gao, W. Tan, Y. Zhao et al., "Diversity in the mechanisms of humin formation during composting with different materials," Environmental Science \& Technology, vol. 53, no. 7, pp. 36533662, 2019.

[13] A. Piccolo, R. Spaccini, A. De Martino, F. Scognamiglio, and V. di Meo, "Soil washing with solutions of humic substances from manure compost removes heavy metal contaminants as a function of humic molecular composition," Chemosphere, vol. 225, pp. 150-156, 2019.

[14] L. Zanin, N. Tomasi, A. Zamboni, D. Sega, Z. Varanini, and R. Pinton, "Water-extractable humic substances speed up transcriptional response of maize roots to nitrate," Environmental and Experimental Botany, vol. 147, pp. 167-178, 2018.

[15] S. Nardi, D. Pizzeghello, C. Gessa et al., "A low molecular weight humic fraction on nitrate uptake and protein synthesis in maize seedlings," Soil Biology and Biochemistry, vol. 32, no. 3, pp. 415-419, 2000.

[16] S. Quaggiotti, B. Ruperti, D. Pizzeghello et al., "Effect of low molecular size humic substances on nitrate uptake and expression of genes involved in nitrate transport in maize (Zea mays L.)," Journal of Experimental Botany, vol. 55, no. 398, pp. 803-813, 2004.
[17] B. Eyheraguibel, J. Silvestre, and P. Morard, "Effects of humic substances derived from organic waste enhancement on the growth and mineral nutrition of maize," Bioresource Technology, vol. 99, no. 10, pp. 4206-4212, 2008.

[18] E. Bijanzadeh, R. Naderi, and T. P. Egan, "Exogenous application of humic acid and salicylic acid to alleviate seedling drought stress in two corn (Zea mays L.) hybrids," Journal of Plant Nutrition, vol. 42, no. 13, pp. 1483-1495, 2019.

[19] G. W. Gee and D. Or, "Particle size analysis," in In Methods of Soil Analysis: Part 4 Physical Methods, Number 5 I., J. H. Dane and G. C. Topp, Eds., pp. 255-293, Soil Science Society of America, Inc., Wisconsin, 2002.

[20] Soil and Plant Analysis Council, Soil Analysis Handbook of Reference Methods, CRC-Press, Boca Raton, FL, USA, 2000.

[21] H. Wibowo, B. H. Purwanto, and S. Notohadisuwarno, "Effect of humic acid and molybdate on phosphate adsorption in typic hapludult of cigudeg, bogor," Ilmu Pertanian (Agricultural Science), vol. 2, no. 3, pp. 119-129, 2018.

[22] O. H. Ahmed, M. H. A. Husni, A. R. Anuar, and M. M. Hanafi, "Effects of extraction and fractionation time on the yield of compost humic acids," New Zealand Journal of Crop and Horticultural Science, vol. 33, no. 2, pp. 107-110, 2005.

[23] Z. Rashid, P. H. Zaidi, M. T. Vinayan, S. S. Sharma, and T. A. Srirama Setty, "Downy mildew resistance in maize (Zea mays L.) across Peronosclerospora species in lowland tropical Asia," Crop Protection, vol. 43, pp. 183-191, 2013.

[24] M. Aqil, C. Rapar, and A. Zubachtirodin, Description of HighYielding Variety of CornFood Crop Research and Development, Agency for Agriculture Research and Development, Ministry of Agriculture of Indonesia, Indonesia, 2012.

[25] P. Sudhakar, P. Latha, and P. V. Reddy, Phenotyping Crop Plants for Physiological and Biochemical Traits, Academic Press, London, 2016.

[26] J. F. Eisele, F. Fäßler, P. F. Bürgel, and C. Chaban, "A rapid and simple method for microscopy-based stomata analyses," PLoS One, vol. 11, no. 10, pp. e0164576-13, 2016.

[27] E. T. S. Putra, I. Issukindarsyah, T. Taryono, and B. H. Purwanto, "Physiological responses of oil palm seedlings to the drought stress using boron and silicon applications," Journal of Agronomy, vol. 14, no. 2, p. 49, 2015.

[28] H. A. Mills and J. B. Jones, Plant Analysis Handbook II. A Practical Sampling, Preparation, Analysis, and Interpretation Guide, Micro-Macro Publishing, Athens, 1996.

[29] R Core Team, R: A Language and Environment Computing, $\mathrm{R}$ Foundation for Statistical Computing, Vienna, Austria, 2013.

[30] F. V. Andrade, E. S. Mendonça, I. R. Silva, and R. F. Mateus, "Dry-matter production and phosphorus accumulation by maize plants in response to the addition of organic acids in oxisols," Communications in Soil Science and Plant Analysis, vol. 38, no. 19-20, pp. 2733-2745, 2007.

[31] R. J. Haynes and M. S. Mokolobate, "Amelioration of $\mathrm{Al}$ toxicity and $\mathrm{P}$ deficiency in acid soils by additions of organic residues: a critical review of the phenomenon and the mechanisms involved," Nutrient Cycling in Agroecosystems, vol. 59, no. 1, pp. 47-63, 2001.

[32] T. Büyükkeskin, Ş. Akinci, and A. E. Eroğlu, "Effects of humic acid on root development and nutrient uptake ofVicia fabaL. (Broad bean) seedlings grown under aluminum toxicity," Communications in Soil Science and Plant Analysis, vol. 46, no. 3, pp. 277-292, 2015.

[33] C. García, B. Ceccanti, G. Masciandaro, and T. Hernández, "Phosphatase and $\beta$-glucosidase activities in humic substances from animal wastes," Bioresource Technology, vol. 53, no. 1, pp. 79-87, 1995. 
[34] K. Yang, L. Guan, J. Zhu, and L. Yan, "Effects of exogenous humic acids on forms of organic phosphorus in three contrasting types of soil," Communications in Soil Science and Plant Analysis, vol. 44, no. 14, pp. 2095-2106, 2013.

[35] D. Zhen-Yu, W. Qing-Hua, L. Fang-Chun et al., "Movement of phosphorus in a calcareous soil as affected by humic acid," Pedosphere, vol. 23, no. 2, pp. 229-235, 2013.

[36] P. M. Kopittke, K. L. Moore, E. Lombi et al., "Identification of the primary lesion of toxic aluminum in plant roots," Plant Physiology, vol. 167, no. 4, pp. 1402-1411, 2015.

[37] L. P. Canellas, F. L. Olivares, A. L. Okorokova-Façanha, and A. R. Façanha, "Humic acids isolated from earthworm compost enhance root elongation, lateral root emergence, and plasma membrane $\mathrm{H}^{+}$-ATPase activity in maize roots," Plant Physiology, vol. 130, no. 4, pp. 1951-1957, 2002.

[38] Y. Zhao, Z. Fan, F. Hu et al., "Source-to-sink translocation of carbon and nitrogen is regulated by fertilization and plant population in maize-pea intercropping," Frontiers in Plant Science, vol. 10, p. 891, 2019.

[39] N. D. H. Maibodi, M. Kafi, A. Nikbakht, and F. Rejali, "Effect of foliar applications of humic acid on growth, visual quality, nutrients content and root parameters of perennial ryegrass (Lolium Perenne L.)," Journal of Plant Nutrition, vol. 38, no. 2, pp. 224-236, 2015.

[40] W. L. Araújo, A. R. Fernie, and A. Nunes-Nesi, "Control of stomatal aperture," Plant Signaling \& Behavior, vol. 6, no. 9, pp. 1305-1311, 2011.

[41] A. C. García, M. Olaetxea, L. A. Santos et al., "Involvement of hormone- and ROS-signaling pathways in the beneficial action of humic substances on plants growing under normal and stressing conditions," Biomed Research International, vol. 2016, Article ID 3747501, 13 pages, 2016.

[42] R. Lotfi, H. M. Kalaji, G. R. Valizadeh et al., "Effects of humic acid on photosynthetic efficiency of rapeseed plants growing under different watering conditions," Photosynthetica, vol. 56, no. 3, pp. 962-970, 2018.

[43] F. C. Cordeiro, C. Santa-Catarina, V. Silveira, and S. R. d. Souza, "Humic acid effect on catalase activity and the generation of reactive oxygen species in corn (Zea mays)," Bioscience, Biotechnology, and Biochemistry, vol. 75, no. 1, pp. 70-74, 2011.

[44] S. Nardi, F. Morari, A. Berti, M. Tosoni, and L. Giardini, "Soil organic matter properties after 40 years of different use of organic and mineral fertilisers," European Journal of Agronomy, vol. 21, no. 3, pp. 357-367, 2004. 